\begin{tabular}{lcccr} 
T H E & A R C H I V E & O F & M E C H A N I C A L & E N G I N E E R I N G \\
\hline VOL. LIX & 2012 & Number 2
\end{tabular}

10.2478/v10180-012-0012-3

Key words: firearm, short barrel recoil, breech mechanisms

JANUSZ EWERTOWSKI *

\title{
BREECH MECHANISM OF A SHORT-RECOIL WEAPON WITH A PROGRAMMABLE MASS SEPARATION
}

\begin{abstract}
Assessing the modern constructions of barrel weapon systems, one can rightly claim that they have achieved a high level of development both in terms of construction and technology. This is confirmed by the fact that it is quite rare for new solutions to appear in this area, with regard to their operational concept. It is also confirmed by many existing classifications of barrel weapons, taking into account the present constructional solutions used. In the present paper, the author described a new type of mechanism, which as for its operational concept, consists in separating the breech parts, being used in the weapons class of a short recoil barrel. The principle of its operation and constructional solution have also been presented, along with the mechanism that has been used so far, which enables us to show the basic operational difference between the two. In order to assess the value of the proposed mechanism, an analysis has also been made of parameters characterizing its operation, contrasted with the parameters of the mechanism used so far. This comparison has been drawn, taking into account the same object of reference, i.e. the NS-23 gun. In the summary, conclusions have been presented assessing the merits of the new solution.
\end{abstract}

\section{Introduction}

There are many different operational mechanisms used in the construction of machines, ensuring their planned performance. These mechanisms, in turn, consist of elements collaborating with each other so that fragmentary tasks of a given machine are accomplished.

Among the mechanisms used we can specify one whose task is to separate moving mass, consisting of more than one element, into individual constituents. Such a solution is used, for instance, in the locking mechanism of a short- recoil weapon. Firearms of this type often try to make use of minor force thrust released against the point of support or fastening. In the

* Faculty of Production Engineering, Warsaw University of Technology, ul. Narbutta 85, 02-524 Warszawa, Poland; e-mail: jewert@interia.pl 
present solutions, the process of mass separation is always abrupt in character, resulting in heavy, instant shock load. During his work on weapon systems, the author of the present paper designed a new mechanism of mass separation based on a different principle of operation than those currently in use. The mechanism will be discussed later and compared with the existing solutions.

\section{Kinematics of the classical and the newly proposed locking mechanism}

The mechanism of mass separation used in short-recoil weapons, which takes place during the barrel kickback makes use of the solution based on the principle of a single-arm lever. The mechanism can be called the classical one. Its general scheme of operation is presented in Fig. 1.
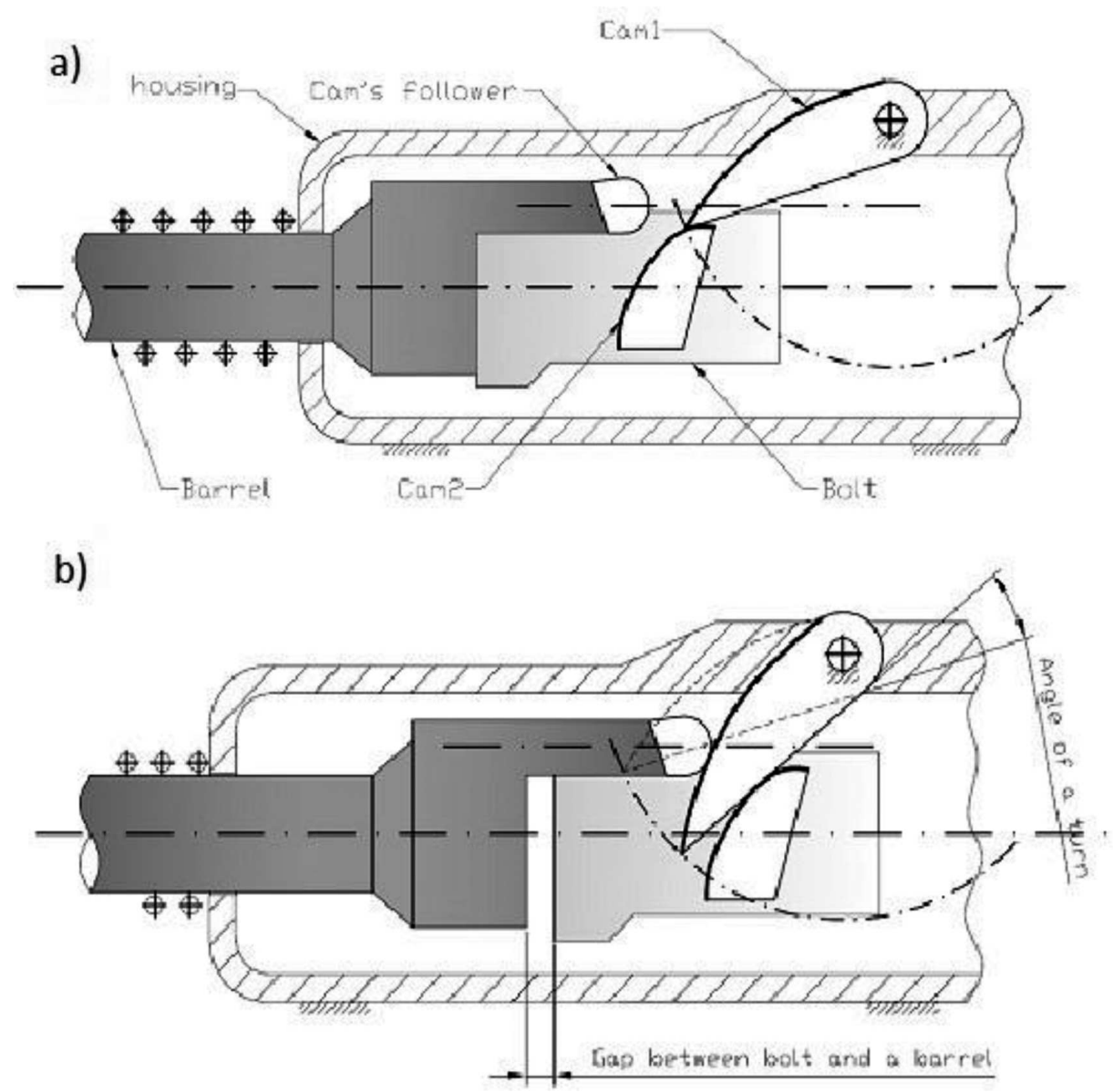

Fig. 1. Functional scheme of the locking mechanism in a short-recoil firearm: a) position of parts at rest, b) position of parts at work 
In this solution, in the resting position, the breechblock pressed by its recoil spring is in its front position resting on its housing. In this type of firearm, the locking mechanism consists of two masses linked by a cam system in such a way that on separating slide the front mass turns around against the rear mass. The turn is used to lock the breechblock. Being in the front position, the locking head is pressed forward against the breech by its spring. Then the front part of the breech is turned into the position closing the barrel, joining the housing and locking the gun. In order to unlock, it is necessary to turn the front part and move it away from the breechblock.. This process is carried out during the recoil of the barrel, taking place on firing. Then the barrel along with the housing and breechblock is kicked back deeper into the weapon housing. After a given displacement, caused by the explosion of powder gases decompressed to a safe level, the buffer In the housing slides upon the lever placed in the weapon housing and unlocking the breech. Then the lever acts on an appropriate surface of the second mass of the breechblock.. Between the points of touch between the buffer and the breechblock there is a rising leverage, as a result of which the second mass starts moving away from the first one, and due to the cam link, it is simultaneously turned around along its longitudinal axis. As a result, it enables unlocking of the breechblock, which is the required function of the above mechanism.

Analyzing the functioning of the above mechanism, one should note that it operates under highly dynamic load. The contact of the buffer firing pin with the lever and the other mass of the breech is of a typical shock type. It is unfavorable, as it results in both high level instant load and an abrupt increase in the initial velocity of the second mass. This velocity is a characteristic feature of a given solution and remains practically unregulated. This question will be discussed further in the present paper.

The possibility of eliminating these defects would be an exceptionally valuable improvement to the operational system of the described construction. Analyzing this problem, one concludes that such a solution is possible. As a new design, it is presented in a schematic form in Fig. 2, showing how such a mechanism functions.

In this solution, the separating mechanism of the breechblock parts has been significantly modified. Instead of a straight lever, an angular two-arm level has been applied, fixed on the barrel mount. Due to this modification, it moves on recoil along with the barrel. One of the arms of the lever cooperates with the controlling cam fixed in the stationary housing of the weapon, while the other arm cooperates with the head of the second mass of the breech. In this situation during the barrel recoil, the turning movement of the lever is forced by the cam. The character of this movement can be precisely 


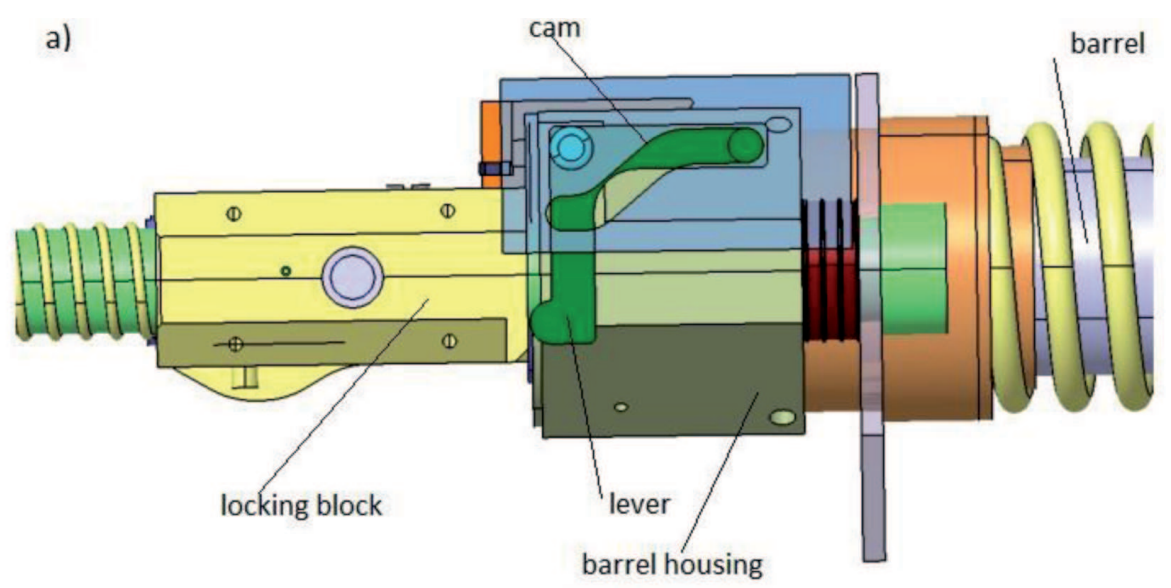

b)
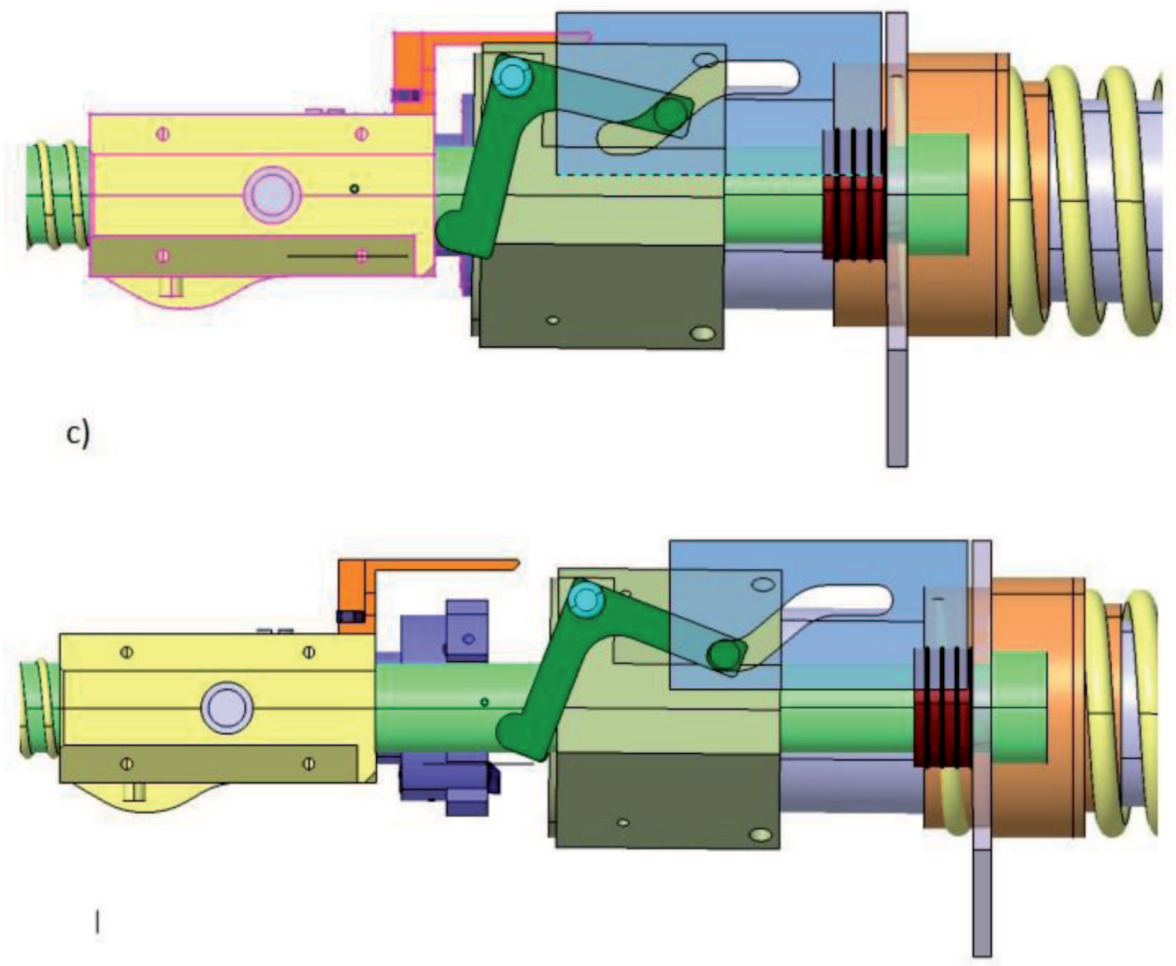

Fig. 2. Newly proposed solution of a breech mechanism: a) position of parts at rest, b) position of parts at work during the barrel recoil, c) position of parts in the final phase of the barrel recoil

programmed by an appropriate definition of the cam profile. During the recoil the turning lever will be acting on the second mass by its operating arm, pushing it away from the other moving parts, and thus carrying out the unlocking process of the breech. Similarly as in the previous solution, 
both masses are linked by a properly shaped controlling cam. This way the designed function of the mechanism will be performed.

The basic advantage of the above solution is, due to the application of a cam, to ensure a programmable and non-shock mass separation. This solution has been tested in practice, which will be discussed later.

\section{Comparing the working characteristics of the two breech mechanisms}

To assess the value of the proposed solution, one can compare the new and the existing design. To this end, one model of weapon equipped with a classical mass separating mechanism was chosen, for which a new mechanism was additionally designed. Next, the introduced changes were closely scrutinized in action. The object of such a comparison was the Soviet antiaircraft $23 \mathrm{~mm}$ gun, commonly known as the NS-23. In this construction, in the case of classical breech masses separation activated by a lever rigidly fixed in the weapon housing, Fig. 3 illustrates how the separation of the two masses is performed.

a)
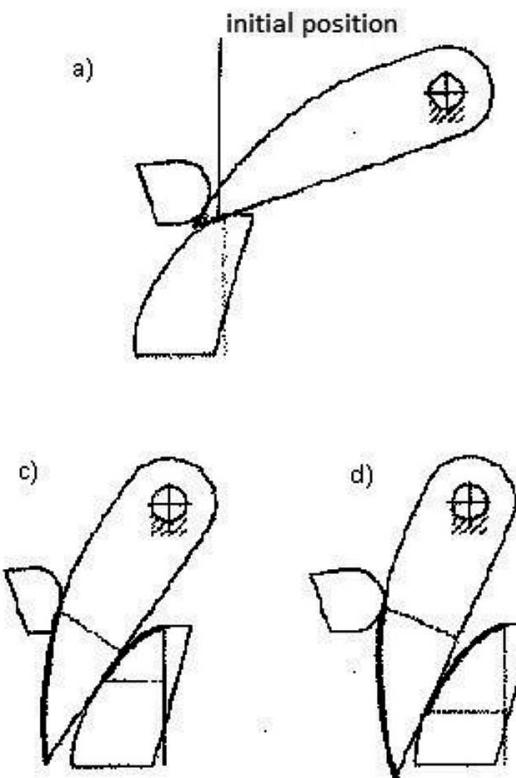

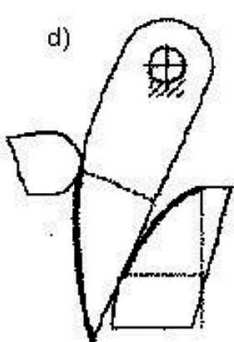

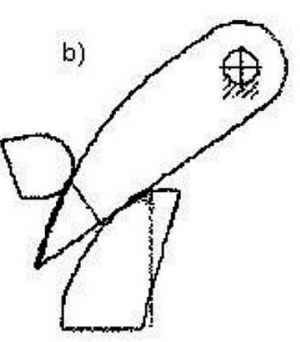

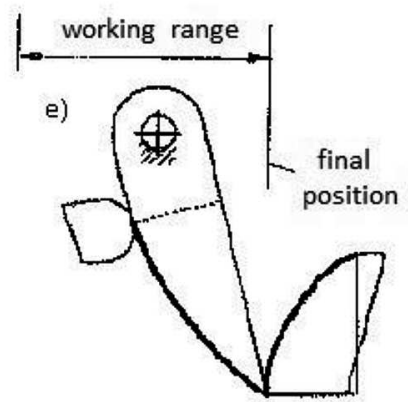

Fig. 3. Scheme of the classic locking mechanism operation of the NS-23 gun a),b),c),d),e) - working stages of the mechanism

Before explaining it further, one should underline that, according to Fig. 3, the mechanism is equipped with a system of two interconnected and cooperating cams. One of them is placed on the lever and the other - 
on the side of the pushed-away part of the breech. During the recoil of the barrel, both cams, in an explicitly designed way, work together. The shift value of the second mass will be the sum of both cam lifts. Therefore, it is possible, for the sake of analyzing the mechanism operation, to propose the introduction of a substitute cam designed according to the principle of lift superposition of individual cams. The guiding principle in a case like this is shown in Fig. 4.

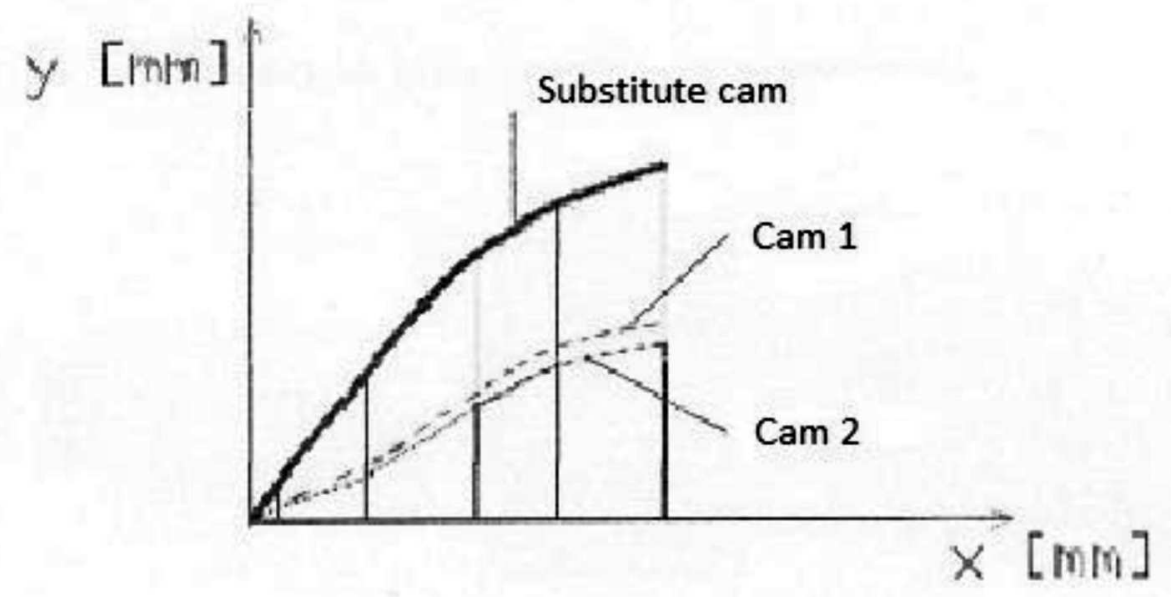

Fig. 4. Scheme of designing a substitute cam on the basis of two known cams

Having a substitute cam profile and knowing the position of the lever points cooperating with appropriate masses, as well as the velocity of the barrel movement and the barrel related masses during the gunshot, one can define the movement characteristics of the mass recoiled. The required velocity was defined by solving a classical recoil problem for the weapon type considered, which is a known issue. Approaching the task in hand, two methods of conduct were considered:

- first, the functional description of a cam profile by means of an analytical continuous function and, further, the application of methods of analytical mathematics. To assess the obtained profile characteristics of a substitute cam, it would seem exceptionally effective to apply a Fourier series, capable of ensuring quick approximation of real operation with a required accuracy and also,

- second, the application of a differential scheme based on real measurements of the lift value of individual cam profiles. 
Taking a decision, in the present case, we assumed the second method was a quicker one with regard to the measurement data at our disposal. Constructing the substitute cam, the lift values of both cams throughout their full operational range were determined, with a $0.5[\mathrm{~mm}]$ step. In effect, a sequence of data was obtained assigning lift values to appropriate shift values of the recoil system, measured along the line of its movement. It enabled us to devise the following relationships:

The velocity will be described as:

$$
v_{i}=v_{i-1}+\frac{s_{i}-s_{i-1}}{\Delta t_{i}}
$$

where $\mathrm{v}_{i}$ - the velocity at the $\mathrm{i}^{\text {th }}$-step,

$\mathrm{s}_{i}-\mathrm{s}_{i-1}-$ mass displacement at the $\mathrm{i}^{\text {th }}$-step,

$\Delta \mathrm{t}_{i}$ - time of movement between the points $\mathrm{s}_{i}$ and $\mathrm{s}_{i-1}$

Consequently, the acceleration and jolt will be described by the relationships:

$$
\begin{aligned}
& a_{i}=a_{i-1}+\frac{v_{i}-v_{i-1}}{\Delta t_{i}}, \\
& u_{i}=u_{i-1}+\frac{a_{i}-a_{i-1}}{\Delta t_{i}}
\end{aligned}
$$

In order to define the characteristics of the aforementioned values, a digital program Matchcad 14 was used, calculating individual values of velocity, acceleration and jolt, and presenting the obtained data in the form of graphs. The obtained data were presented in Fig. 5, in the form of diagrams characterizing the operation of the analyzed mechanism.

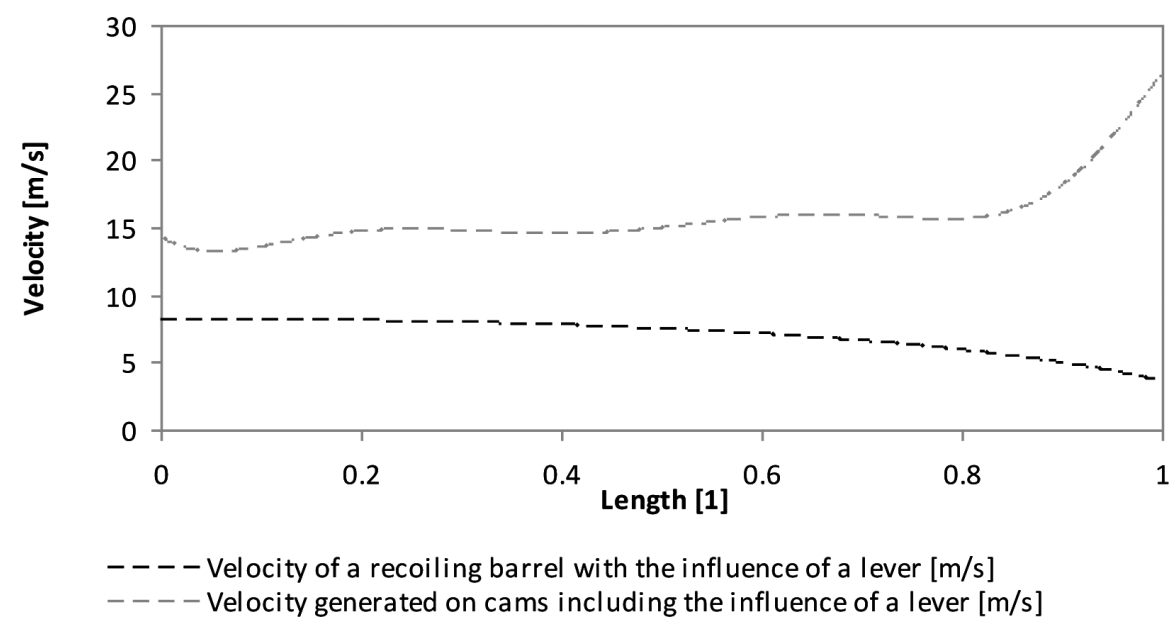



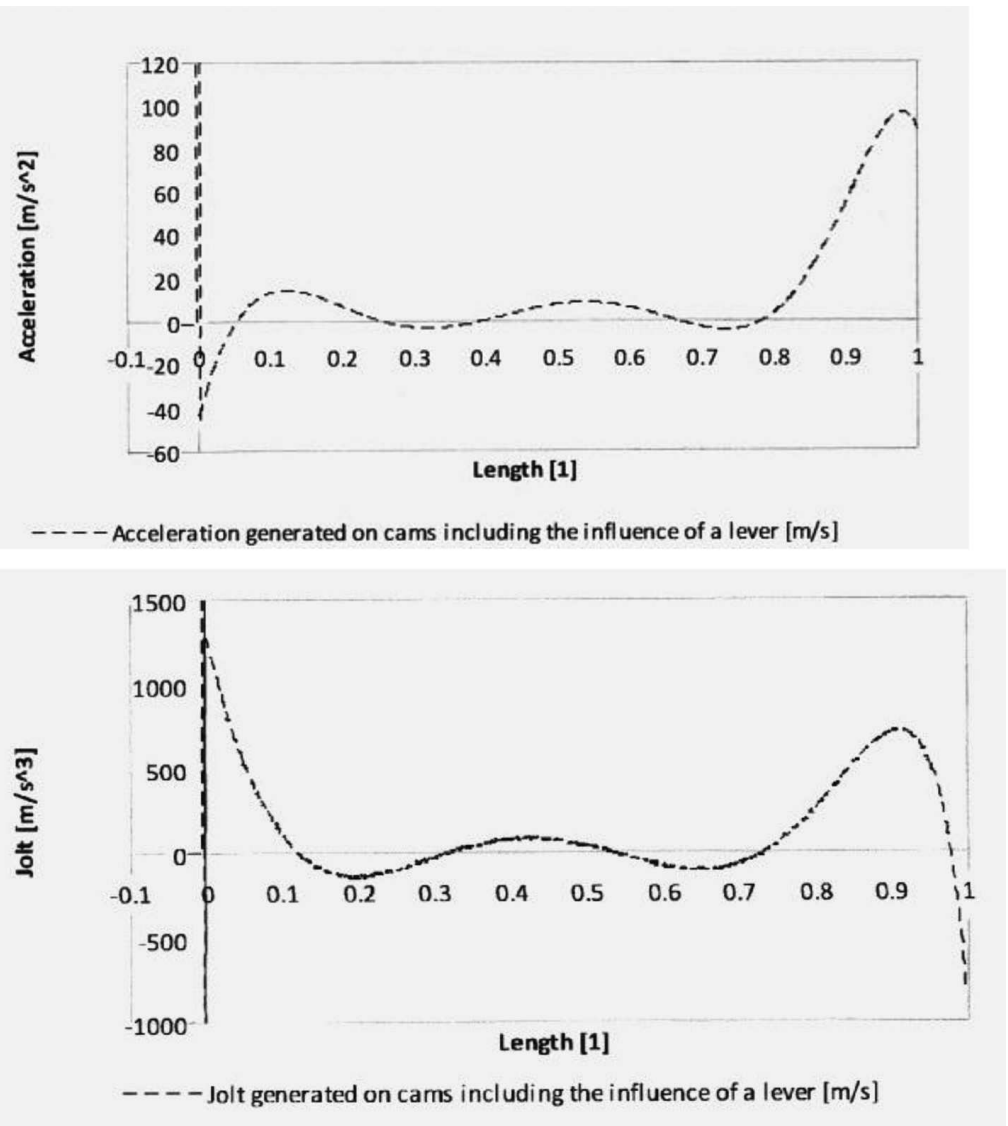

Fig. 5. Characteristics of velocity, acceleration and jolt of the recoiled mass, generated in the mechanism separating the breech parts of the N-S gun

As it has been expected, and confirmed by the presented graphs, the functioning mechanism is characterized by its high impact operation, especially at its initial stage. The separation of breech parts starts with an abrupt velocity increase generated on the recoiled mass. As a result, at the start, there is, theoretically, an infinitely great acceleration of movement and a likewise jolt. Obviously, in reality, these values would be great but finite, as a result of elastic strain of individual elements. The level of strain will, however, result in growing, permanent deformations of the surfaces working together, the effects of which are clearly visible on the graphs presented above. It concerns mainly the acceleration graph, where the acceleration changes from an infinitely great value to an adverse one, which is theoretically impossible according to the operational principle of the mechanism. Additionally, it should be noted that lift measurements of individual cams were taken on a gun which had ceased to be used or, practically, the one 
where the working surfaces of cams had been permanently deformed. The downside is also the fact that the velocity at which the separated breech part is driven is unregulated as it is defined by the positioning of the separating lever and the velocity of the recoiled system characteristic of a given solution. In such a case the value of the aforementioned velocity becomes a permanent element of a given solution. Summing up, we can state that the application of the described solution is not favorable from the point of view of the existing strain and consequently, the durability of individual elements. It is being used as no other solution has been known.

The aforementioned defects can be eliminated by applying the new modified mechanism. To explain the different principle of its operation as opposed to the mechanism used so far, in Fig. 6 a distinct kinematic - dimensional scheme of the new solution is presented.
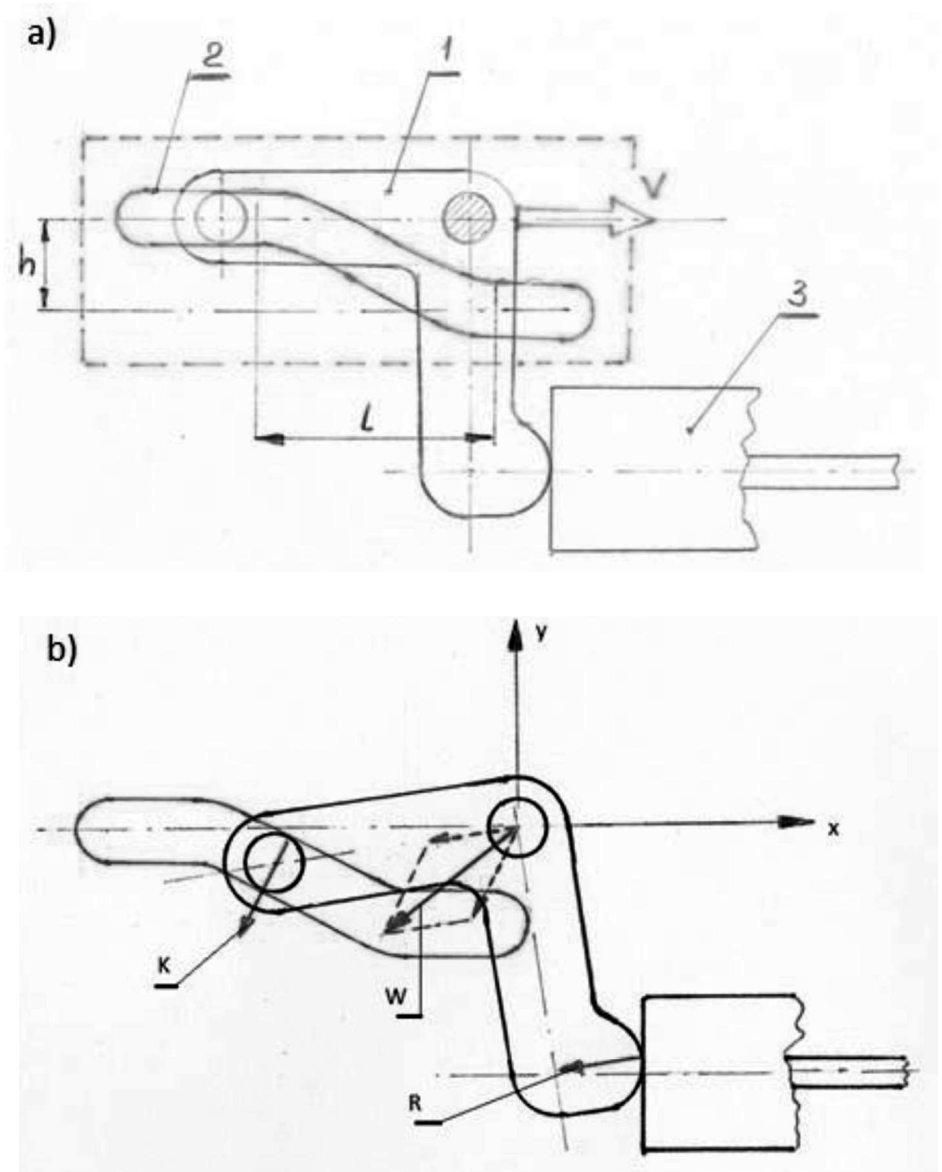

Fig. 6. a) Operation scheme of a breech mechanism proposed for a short recoil barrel b) Forces operating on the lever during work time 
1. movable separating lever,

2. cam mounted on a stationary casing of the gun,

3. kicked-back mass.

$\mathrm{V}$ - velocity and direction of the separating lever movement,

I - working length of the cam,

$\mathrm{h}$ - cam travel,

$\mathrm{K}$ - reaction from cam side,

$\mathrm{R}$ - reaction from kicked-back mass side,

$\mathrm{W}-$ resultant forces weighting on lever rotation axis.

What is interesting about the present mechanism is the fact that it has two types of leverage producing a cumulative effect on the moved mass. The first one can be called the velocity type, and it consists in the fact that the lever traveling at velocity $\mathrm{V}$ covers the working length 1 of the cam in a specific time. At the same time, the arm of the lever cooperating with a cam slide guide moves a distance corresponding to the cam travel $\mathrm{h}$, assuming that both lever arms are of equal length. Taking into account the fact that length 1 is several times longer than travel $\mathrm{h}$, the result is the leverage slowing down the velocity generated on the moved mass. It is a desirable effect, favorable for the mechanism. The second leverage, which can be called mechanical, is an ordinary leverage of a two-arm lever resulting from the arm lengths applied.

However, the basic value and advantage of the new mechanism is the possibility of programming the time characteristics of movement parameters of the shifted mass. It can be done due to, practically, unlimited possibility of designing the shape of the cam controlling the turn of the moving lever. It results in possible elimination of jolt strain dangerous for reliable and failure-free operation of the mechanism and, by the same token, the whole weapon. The mere application of relatively technologically simple cams of a trigonometric profile enables us to obtain the strain of specific and, first of all, finite value, occurring between the cooperating breech elements, and, first of all, finite value.

One of the possibilities of showing functional differences between these two compared mechanisms is to perform the analysis of operational dynamics of the new solution and then compare the obtained results with the characteristics of the system used so far. In weapon construction, it is particularly important to define energetic states of individual elements during the operation of a given mechanism, such as kinetic energy transferred to individual subsystems when a shot is fired determines the feasibility of the tasks set for a given mechanism. For the above reasons, in the present case a method of operational dynamic analysis was suggested, which considers energetic states 
of individual elements in time. This method differs from classical equations of movement but as it takes into account the specificity of the analyzed object, it was considered to be more justifiable.

For a short-recoil weapon the source of initial energy is the recoil system acquiring its energy as a result of shot firing. It usually has more energy than it needed by individual mechanisms. As a result, in the final stage of operation, the recoil system transfers the supplied energy to the entire weapon mounts in the firing post. An overall operational scheme of this type of weapon as well as energy propagation is presented in Fig. 7.

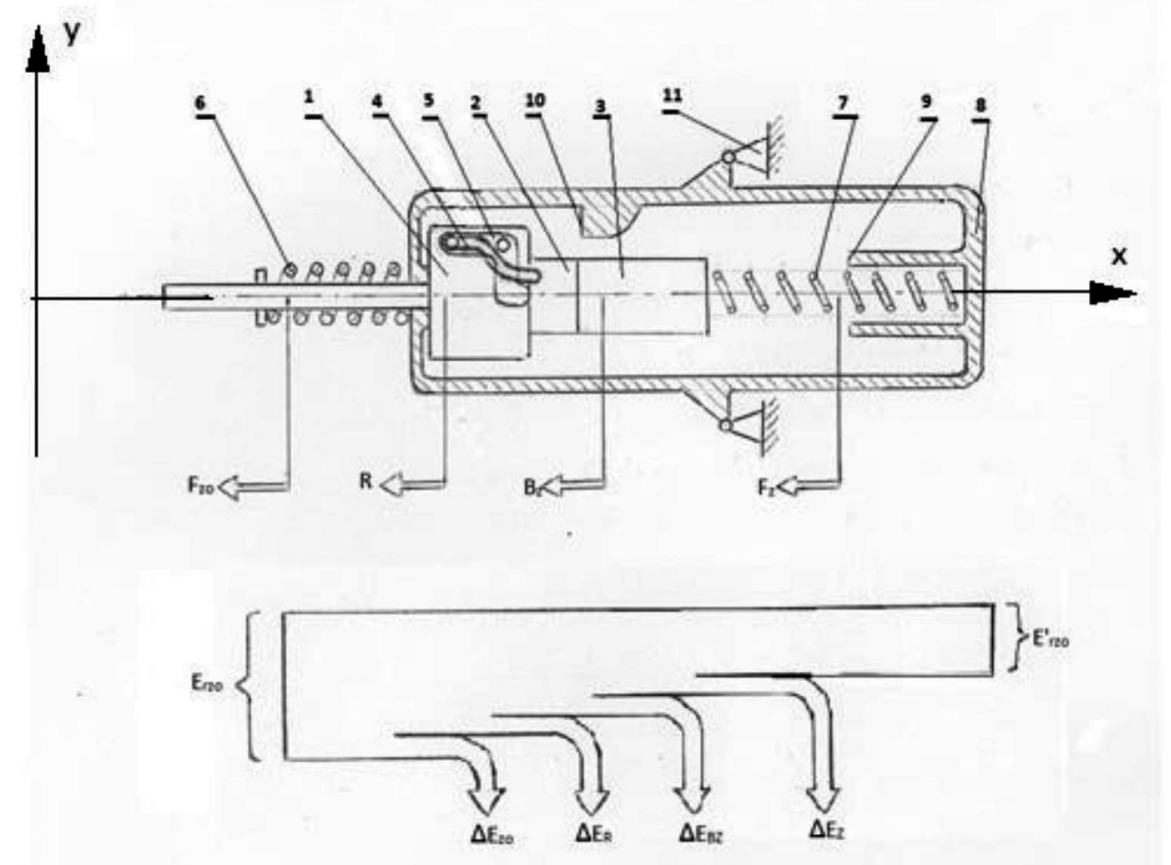

Fig. 7. Operational scheme of a short recoil weapon and accepted energy propagation in the system

1. Recoil system, 2.Breechblock, 3.Slide, 4.Steering cam, 5.Separating lever, 6. Recoil spring of the recoil system, 7.Breech block spring, 8. Housing, 9. Breech buffer, 10.Buffer of the recoil system, 11 .Mountings for the firing post.

In compliance with the symbols in Fig. 7, the following values will be introduced for further analysis:

$\mathrm{F}_{z o}$ - resistance force of the recoil spring,

$\mathrm{R}$ - resistance force of internal friction,

$\mathrm{B}_{z}$ - inertial force existing in the acceleration phase of the breech system, 
$\mathrm{F}_{z}$ - resistance force of the breech block recoil spring,

$\Delta \mathrm{E}_{R}$ - energy loss due to internal resistance,

$\Delta \mathrm{E}_{\mathrm{ZO}}$ - energy taken over by the recoil spring of the recoil system,

$\Delta \mathrm{E}_{B Z}-$ energy used for breech acceleration,

$\Delta \mathrm{E}_{Z}$ - energy taken over by the breech recoil spring,

$\mathrm{E}_{R Z O}$ - initial energy of the recoil system,

$\mathrm{E}_{R Z O}^{1}$ - final energy of the recoil system.

Analyzing how the weapon in question operates, we can find out that it is enough to confine our analysis only to the phase separating the breech block from the recoil system in order to show operational differences between the new mechanism and the one used so far.

$$
V=\frac{m_{p} v_{o}}{M_{o}}
$$

where: $\mathrm{m}_{p}$ - bullet mass,

$\mathrm{V}_{o}$ - initial bullet velocity,

$\mathrm{M}_{o}$ - recoil system mass.

Consequently, the initial energy of the system will be:

$$
E_{R Z O}=\frac{m_{p}^{2} v_{o}^{2}}{2 M_{o}}
$$

The initial kinetic energy of the recoil system, which can be called source potential, will be successively used up:

- to overcome mechanical resistance,

- to stretch the recoil spring of the recoil block,

- to accelerate further the breech block,

- to tighten the recoil spring of the breech block.

- for investigating energy propagation in such a system, we can define first energetic states of individual elements and then their movement parameters. In the case in question, this task was performed by a numerical method. To meet this aim a program was devised, calculating energy propagation and movement parameters of specific elements. Calculations were made for any given step $\mathrm{s}$ that the recoil block is moved. The following interrelationships were assumed for every step:

1. Energy loss to overcome mechanical resistance:

$$
\Delta E_{R}(i)=R s
$$

where: $\Delta \mathrm{E}$ (i) - denotes the change in energy state of a given element at the $\mathrm{i}^{\text {th }}$ step, 
$\mathrm{R}$ - is the averaged constant value of resistance.

2. Energy taken over by the recoil spring of the recoil block

$$
\Delta E_{Z O}(i)=k_{l} s^{2}
$$

where : $\mathrm{k}_{l}$ - the spring stiffness of the recoil block

3. Acceleration energy of the recoil breech mass

$$
\Delta E_{B Z}(i)=\frac{1}{2} m_{s} \frac{v_{i}-v_{i-1}}{t_{i}} s+\frac{1}{2} I_{z} \omega(i)^{2}
$$

where: $I_{z}$ - the moment of inertia of the breech against the axis of rotation

$\mathrm{v}_{i}-$ the breech block velocity against the recoil block at the $\mathrm{i}^{\text {th }}$ step, where in:

$$
v_{i}=\frac{y_{i}-y_{i-1}}{t_{i}}
$$

The value y denotes the shift of the breech block against the recoil block at individual steps. It depends on the assumed cam profile controlling the rotation of the separating lever. Generally, the values $\mathrm{y}$ and $\mathrm{x}$ are interrelated, which can be written as follows:

$$
y=y(x)
$$

and the angular velocity of the breech rotation:

$$
\omega(i)=\frac{\varphi_{i}-\varphi_{i-1}}{t_{i}}
$$

$\varphi$ denotes the angle of breech rotation, being a complex function as $\varphi=\varphi(\mathrm{y}(\mathrm{x}))$ while in every case it denotes time taken by the $\mathrm{i}^{\text {th }}$ step.

4. Energy taken over by the recoil spring of the breech block

$$
\Delta E_{z}(i)=\frac{1}{2} k_{z} s^{2}
$$

where: $\mathrm{k}_{z}$ - the spring stiffness of the breech block.

After taking one step s, the recoil block will decrease its energy by a total of energy in excess of the above described, which can be written as follows:

$$
E_{R Z O}(i)=E_{R Z O}(i-1)-\left[\Delta E_{R}(i)+\Delta E_{Z O}(i)+\Delta E_{Z O}(i)+\Delta E_{Z}(i)\right]
$$

At this moment, thel energetic states of all system elements are known, which means that their parameters can be also precisely defined. Having the solution for a given step, we can make subsequent calculations for the next step. 
The discussed methodology was used to make an operational analysis of the aforementioned gun NS-23, with an assumption that a new breech unlocking mechanism has been installed. It enabled us to compare directly both mechanisms. At the same time, such a move facilitated considerably such input data as elements mass, spring rate, firing impact parameters, etc. Moreover, it was assumed that a trigonometric contour will be used of cam profiles, described by the function:

$$
y=a\left(1-\frac{\cos (x \pi)}{2 l}\right)
$$

After such an assumption, numerical calculations were made, simulating the work of the gun mechanisms during the phase of breech block acceleration. The obtained results are shown in Fig. 8, graphically presenting velocity and acceleration rates in relation to the recoil block and impact. All the graphs are shown as functions of time.

The analysis ends at the point when the separating lever acceleration becomes negative because this is the moment the breech block is separated and the acceleration phase ends. As the graphs show, the proposed new solution of the mechanism in question works quite differently from the existing one. The initial velocity of recoil starts from level zero, while movement acceleration retains its finite value and continuous character throughout the entire phase. In sum, the new mechanism should be considered as meeting the assumptions made about its functioning, which ensures a significant improvement in the entire gun's mechanics.

In our case, as a certain drawback should be considered the high level of impact occurring at the initial phase of the movement. However, it is the consequence of the assumed contour of the steering cam profile, which is not a surprise. This problem can be easily solved, however, by applying different initial assumptions concerning the selection of the cam profile in question. The selection of the optimal cam profile for a given mechanism was considered a separate question to be discussed in another article.

\section{Conclusions}

Assessing the new solution, one can formulate a number of conclusions, namely:

1. It has been demonstrated that in weapons with a short recoil barrel the proposed mechanism of breech parts separation can be used instead of the one that has been used so far, resulting in significant improvement of the equipment functioning. 

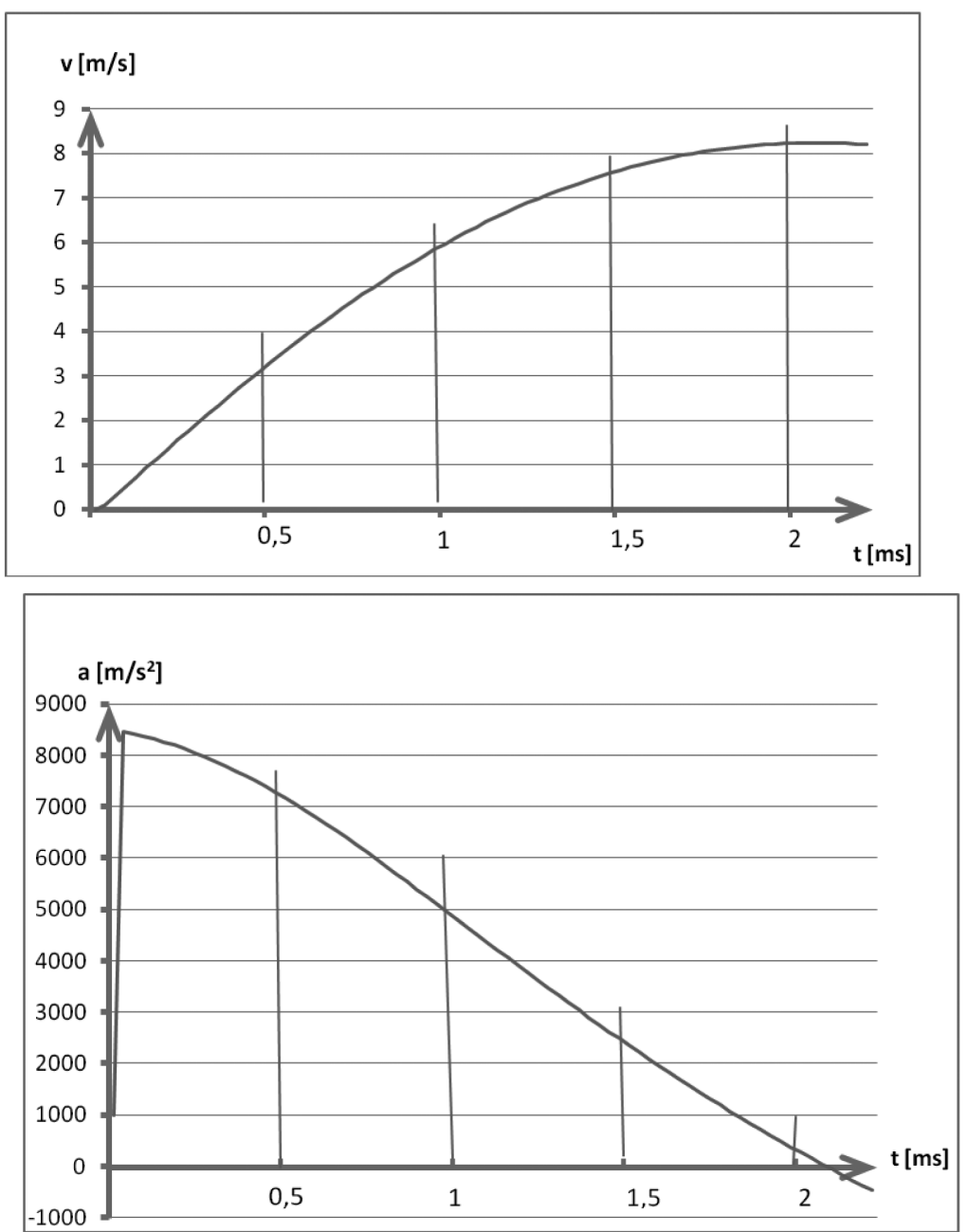

2. The proposed mechanism, due to the change In the operation principle and possibility of designing the profile of the controlling cam, allows us to obtain much lower recoil energy of the whole breech system. It produces a number of positive effects such as lower strain on breech mechanism elements, better durability, lower energy generated on the weapon casing, gentler effect on the weapon user, greater firing accuracy, etc.

3. The proposed way of constructing the cam profile should be treated as one of the possible solutions. It is suggested that future research on the cam profile should account for a greater number of initial conditions.

4. The application of the proposed solution in short recoil weapons should be considered innovative and instrumental in developing weapon systems. 


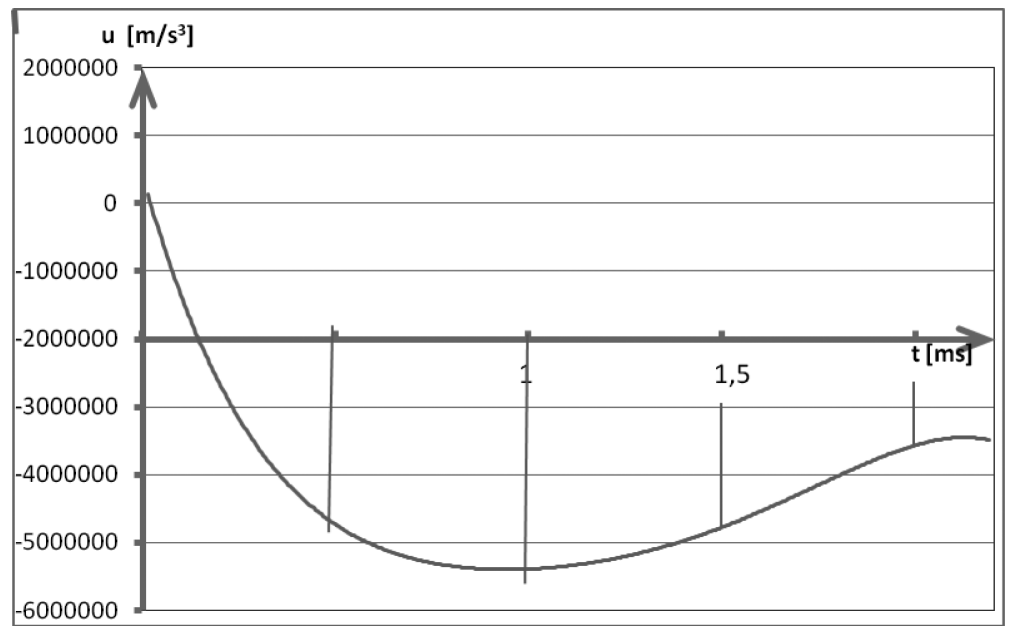

Fig. 8. Velocity, acceleration and impact rates defined against the recoil block, obtained as a result of numerical calculations for the recoiled breech block

Due to these reasons it was registered in the Polish Patent Office

Manuscript received by Editorial Board, July 10, 2011; final version, May 28, 2012.

\section{REFERENCES}

[1] Wilniewczyc P.: Broń samoczynna - Wyd. MON 1958.

[2] Głowicki H.: Zasady konstrukcji automatycznej broni strzeleckiej - Wyd. WAT 1966.

[3] Orłow W.: Projektirowanie rakietnych i stwolnych sistiem - Maszinostrojenie 1974.

[4] Alfierow W.: - Konstrukcija i rascziot awtomaticzeskowo orużia - Maszinostrojenie 1977.

[5] Foss C. Jane's: - Armour and artillery 2007-2008, 2009-2010 - England.

[6] Foss C. Jane's: - Infantry weapons 2007-2008 - England.

[7] Surma Z., Szmit L., Torecki S., Wożniak R.: Model matematyczny podrzutu broni działającej na zasadzie odprowadzenia gazów - Problemy Mechatroniki nr 2 - 2010.

[8] Surma Z., Szmit Ł., Torecki S., Wożniak R.: Niektóre wyniki badań symulacyjnych wpływu charakterystyk konstrukcyjnych karabinka automatycznego na jego odrzut i podrzut Problemy Mechatroniki nr 2 - 2011.

[9] Ewertowski J.: Analiza siły oddziaływania broni na strzelca w czasie strzału. Biul. WAT Warszawa 2007 Vol. 1.

[10] Frączek J., Wojtyra M.: Kinematyka układów wieloczłonowych. Metody obliczeniowe - WNT 2007.

[11] Ozmen D., Kurt M., Ekici B., Kaynak Y.: Static, dynamic and fatigue analysis of a semiautomatic gun locking block - Engineering Failure Analysis 16 - 2009.

[12] Hopkins D.A.: Modeling gun dynamics with three dimensional beam elements. Six U.S. Army Symposium on gun dynamics volume I of II, Tamiment, Pensylwania 1990.

[13] Benzkofer P.D.: Dynamic analysis of shoulder-fired weapons - Seventh U.S. Army Symposium on gun dynamics, Newport, Rode Island, 1993.

[14] Wilkersons S.: Modeling of gun dynamic using the three-dimensional finite elements (FE) techniques. 14-th International Symposium on Balistics, Qebec 1993. 
[15] Gacek J., Małachowski J., Płatek P., Woźniak R.: Wstępna analiza procesu dynamicznego oddziaływania tłoka gazowego z suwadłem dla modułowego systemu broni strzeleckiej kalibru $5,56 \mathrm{~mm}$ - Mechanik nr 7/2010.

[16] Damaziak K., Małachowski J., Płatek P., Wożniak R.: Analiza możliwości wykorzystania różnych metod numerycznych w procesie projektowania układu automatyki broni strzeleckiej kalibru 5,56 mm - Mechanik nr 2/2011.

[17] Damaziak K., Małachowski J., Płatek P., Wożniak R.: Badania wpływu zmiany parametrów masowo-bezwładnościowych podzespołu suwadła na charakterystyki kinematyczne karabinka standardowego - Mechanik nr 7/2011.

[18] Damaziak K., Małachowski J., Płatek P., Wożniak R.: Badania sztywności materiału zderzaka suwadła w aspekcie dynamicznej odpowiedzi układu automatyki karabinka standardowego MSBS-5,56. Biuletyn Naukowy WITU Problemy Techniki Uzbrojenia Zeszyt 117/2011.

[19] Headquaters U.S. Army Material Command. Engineering Design Handbook, Gun series, Automatic weapon. 1970.

Mechanizm zamkowy broni $\mathrm{z}$ krótkim odrzutem lufy $\mathrm{z}$ programowalnym rozdzielaniem mas

\section{Streszczenie}

Oceniając współczesne konstrukcje uzbrojenia lufowego można z pełnym uzasadnieniem twierdzić, że osiągnęły one wysoki poziom rozwoju zarówno konstrukcyjnego jak i technologicznego. Potwierdza to obserwowany fakt, że jest rzeczą bardzo rzadką, aby w tym obszarze pojawiały się nowe, co do koncepcji działaniowej, rozwiązania. Świadczy o tym również wiele istniejących klasyfikacji broni lufowych opracowywanych pod względem stosowanych rozwiązań konstrukcyjnych. W przedstawionym artykule prezentowany jest nowy, co do zasady działania, mechanizm rozdzielania mas zamkowych stosowany w klasie broni z krótkim odrzutem lufy. Omawiana jest zasada działania i rozwiązanie konstrukcyjne, a równolegle charakteryzowany jest także mechanizm dotychczas stosowany co umożliwia wykazanie zasadniczej różnicy w działaniu obu mechanizmów. W celu oceny wartości proponowanego mechanizmu wykonana jest również analiza parametrów charakteryzujących jego pracę i porównana ze stosownymi parametrami dotychczas stosowanego mechanizmu. Porównanie to wykonane jest wykorzystując do tego celu ten sam obiekt odniesienia tj. działko lotnicze NS-23. W podsumowaniu przedstawione są wnioski oceniające nowe rozwiązanie. 